UDC 621.314 .26

O. Levon, Ph.D.

National Technical University "Kharkiv Polytechnic Institute",

Bahaliia str. 21, Kharkiv, Ukraine, 61002.

\title{
Simulation of transient processes in low-frequency channel of the semiconductor regulated compensator
}

The simulation of transient processes in lowfrequency channel of the semiconductor twochannel regulated compensator of inactive components of total power is presented in given article. New control methods for two-channel compensator that allow to provide a high performance of the converter in the changing character of the load are proposed. Conclusions of obtained results are presented. References 7, figures 4.

Keywords: power electronics; reactive power control; active power filter; thyristor binary compensator.

\section{Introduction}

System analysis of power quality supply, analysis and development of power theories, analysis of compensation systems of total power inactive components showed the construction possibility of multi-functional compensators of inactive components of total power, which are able to suppress high current harmonics that are consumed by load from power network; to compensate reactive component of network current fundamental harmonic; to symmetrize currents in phases of three-phase circuit; to suppress zero sequence currents.

\section{Problem statement}

Currently two-channel compensator had been developed and it is based on the principle of a twochannel structure in the power circuit. The power circuit of the device is the compensated controlled rectifier, that consists of the low and the high frequency channels. The power circuit is shown in $[1,7]$.

The control system of compensator is based on modern power theories and forecast control ideas. Control algorithms of dual channel compensator and control software in real time are considered in [2-5].

Matlab model of a two-channel semiconductor compensator with digital forecasted control system is shown in Fig. 1.

The model includes two gate groups $\mathrm{GG}_{G}$ and GGT of the low frequency channel with active- inductive load, the active power filter - APF, the digital processing block DPB, the reactor $\mathrm{L}$, the capacity $C$ with the diode group $D G$ and the pulses distribution block PDB.

The flow of current through the reactor is provided by bridge on the lockable thyristors or thyristor bridge on the single-purpose. It depends on the sign of the reactive power on the compensator input. The proposed algorithm assumes control of the reactive power sign and, when it changs, ensures current transfer from one to another rectifier.

The control algorithm with forecast assumes the calculation of angle $\alpha_{0}$, at which by the time of next switching control with angle $\alpha_{1}$, load current will have reached the set value. The current angle $\alpha_{0}$ is defined in the point when functional expressions for $\mathrm{F} 1$ and $\mathrm{F} 2$ equal to zero. Functionals $\mathrm{F} 1$ and $\mathrm{F} 2$ of the algorithm calculate in accordance with following expressions, which represent the implementation of proportional control law and include reactor parameters $R_{L}$ and $L_{L}$, the amplitude of transformer secondary winding voltage $U_{2 m}$, reference current $i^{*}$ ref and load current $i^{*}$ Lo at the time of thyristor unlocking at an angle $\alpha_{0}[1]$.

$$
\begin{aligned}
& F 1=\frac{U_{2 m}}{k\left(L_{L} \cdot \omega+R_{L}\left(\frac{\pi}{6}+\frac{\alpha_{1}-\alpha_{0}}{2}\right)\right)} \cdot\left(\sin \left(\alpha_{1}+\frac{7}{6} \pi\right)-\right. \\
& \left.-\sin \left(\alpha_{0}+\frac{5}{6} \pi\right)\right)-i^{*}{ }_{r e f}+i^{*}{ }_{L 0}=0 \\
& F 1=\frac{U_{2 m}}{k\left(L_{L} \cdot \omega+R_{L}\left(\frac{\pi}{6}+\frac{\alpha_{1}-\alpha_{0}}{2}\right)\right)} \cdot\left(\sin \left(\alpha_{1}+\frac{1}{6} \pi\right)-\right. \\
& \left.-\sin \left(\alpha_{0}+\frac{1}{6} \pi\right)\right)-i^{*}{ }_{r e f}+i^{*}{ }_{L 0}=0
\end{aligned}
$$

The control algorithm is shown in Fig. 2. If sign of load reactive power changes from positive to negative, the current translation from gate group VGT to gate group BGG comes at time when the load current of the rectifier becomes zero and the single-purpose thyristors going off.

If the sign of the reactive power load has become positive, that is, it should ensure the transition from the $\mathrm{GG}_{\mathrm{T}}$ to $\mathrm{GG}_{\mathrm{G}}$, the algorithm ensures the required conditions of the current translation in 
single-purpose thyristors, providing the minimum duration of the transition process.

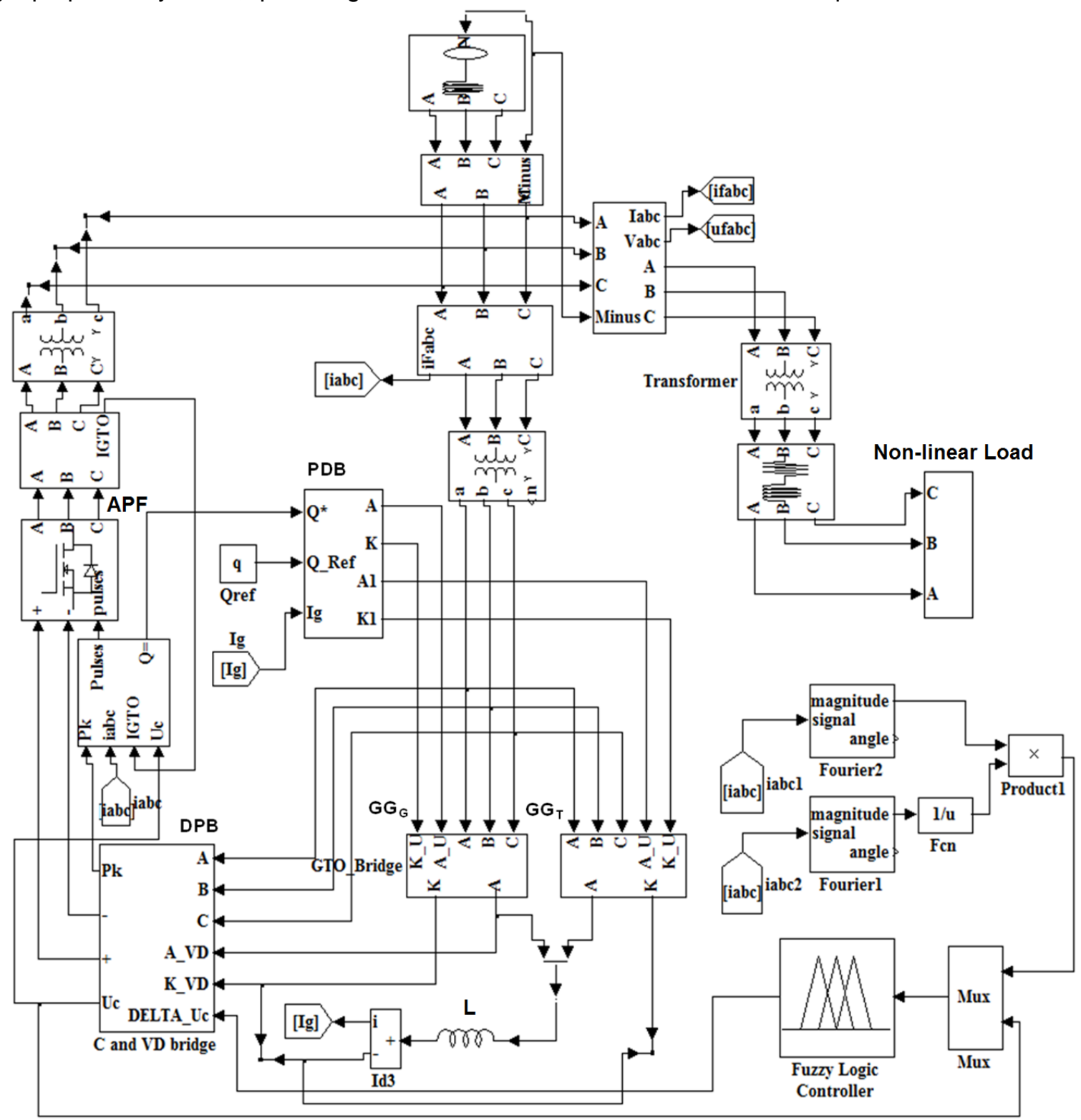

Fig. 1. The Matlab - model of compensator with digital forecast control system

Calculated ratios were implemented and tested using Matlab-model of compensator in static and dynamic modes.

Fig. 3 shows a compensator rectifier reactor current Ir, and the current average value of reactive power $Q_{T}$ at the connection point of reactive power source and compensator to the network when the sign of the set value of reactive power $Q_{z}$ changes from positive to negative, that is, when the mode switches from the reactive power consumption from the network in the generation mode, and the transition from $\mathrm{GG}_{\mathrm{T}}$ to $\mathrm{GG}_{\mathrm{G}}$. Fig. 4 shows transient processes when load reactive power $Q_{N}$ changes.

On the given oscillograms, improvement of the current increment takes several measures of rectifier low-frequency channel working. 

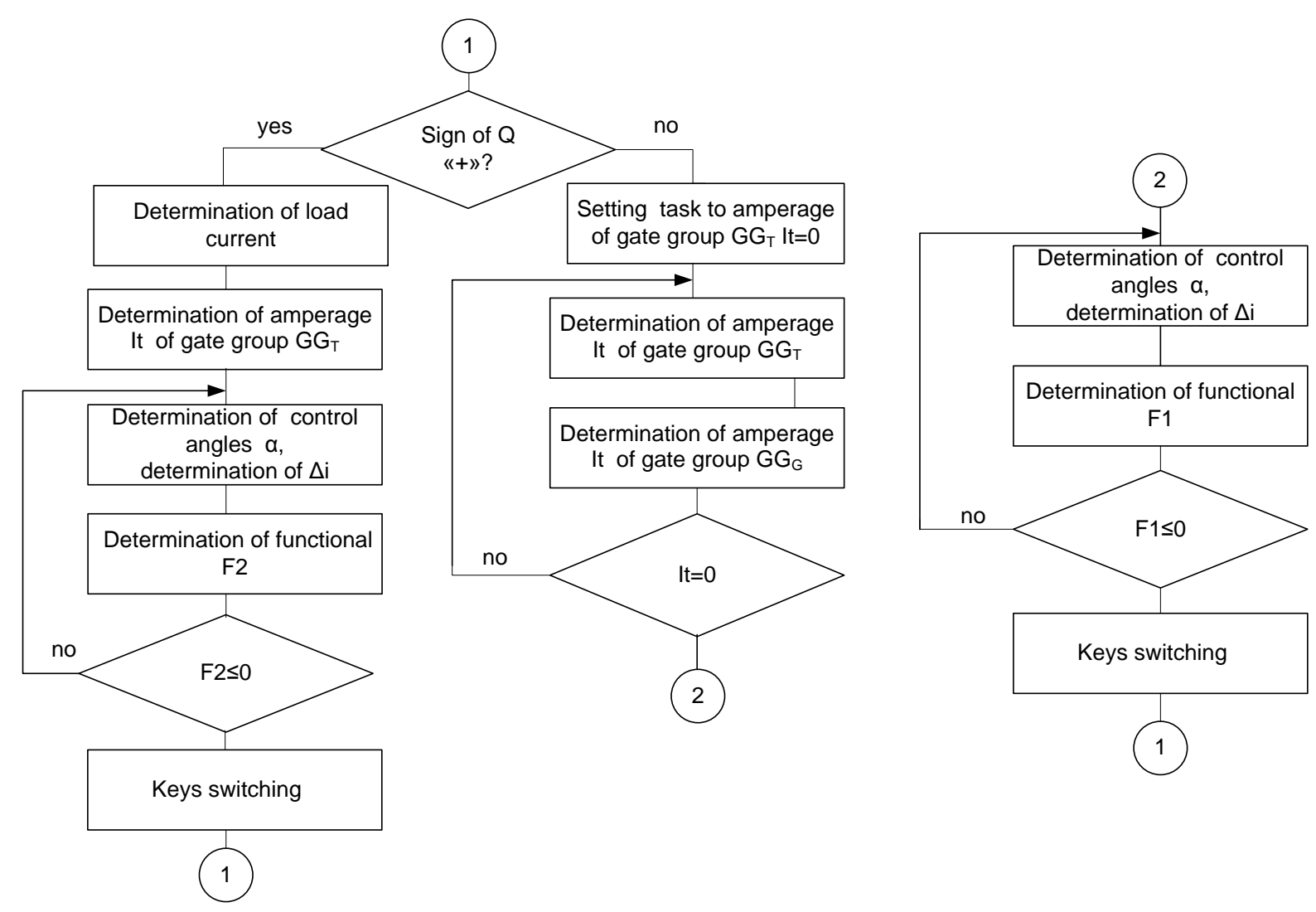

Fig. 2. The control algorithm of low-frequency channel of the compensator when the sign of load reactive power changes from «+» to «-»

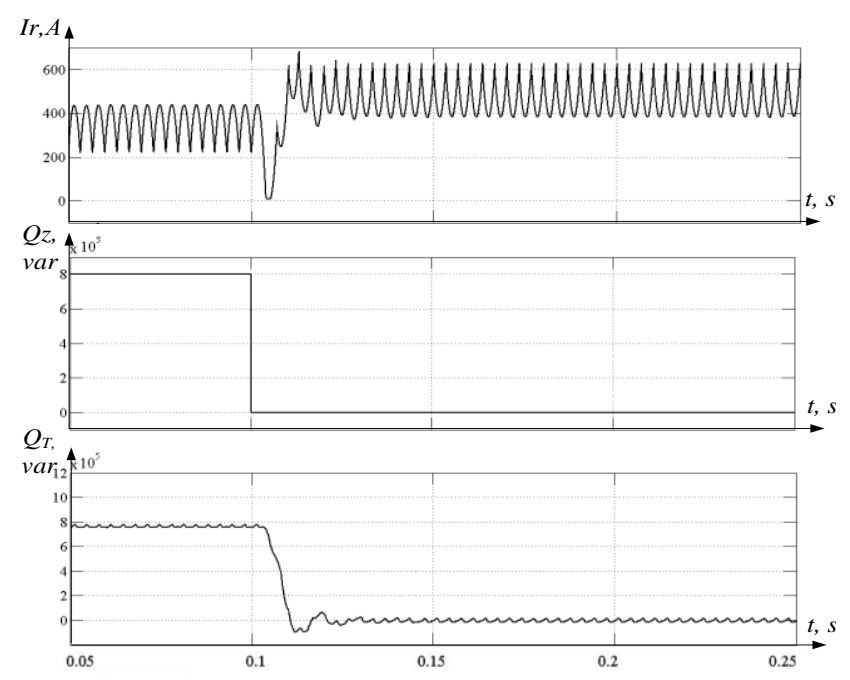

Fig. 3. Transient processes when the sign of load reactive power changes from «+» to «-»

\section{Conclusion}

The experiments confirmed the efficiency of the proposed algorithm applied to the management of double-bridge rectifier operating in reactive power compensation mode.

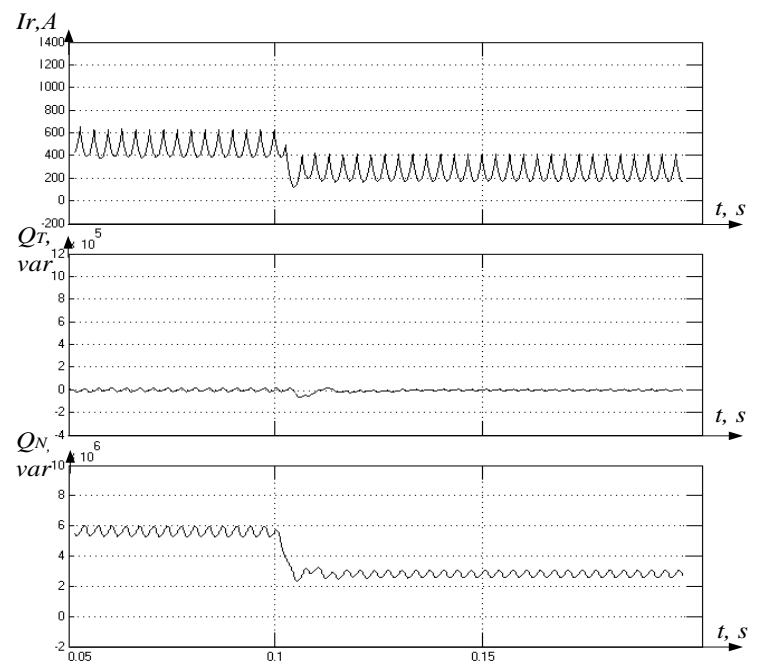

Fig. 4. Transient processes when load reactive power changes

Using the proposed control algorithm for twochannel compensator with forecast control system leads to an improvement in the dynamic characteristics of the compensator when a predetermined value of reactive power in the supply network changes and when the reactive power, that is consumed or generated by the load, changes. 


\section{References}

1. Domnin, I. F., Kaida, E. A. (2009). Dinamicheskie harakteristiki dvuhmostovogo nizkochastotnogo kanala kompensatora neaktivnoi moshnosti. Tehnichna electrodynamika. Kiev. IEDNANU. P. 4. Tematchnui vup. Pp. 63-67. (Rus)

2. Domnin, I. F., Kaida, E. A. (2010). Mnogokonturnaya Sistema upravleniya philtrokompensiruyushim ustroistvom. Tehnichna electrodynamika. Kiev. IEDNANU. P. 2. Tematchnui vup. Pp.44-47. (Rus)

3. Kaida, E. A. (2011). Nechetkoe regulirovanie ustroistvom compensacii neactivnuh sostavlyaushih polnoi moshnosti. Tehnichna electrodynamika. Kiev. IEDNANU. P. 1. Tematchnui vup. Pp.184-188. (Rus)

4. Domnin, I. F., Levon, O. O.,Severin V.P. (2012). Optimizaciya parametrov cifrovogo nechetkogo regulyatora. Tehnichna electrodynamika. Kharkiv: NTU«KHPII». P.2, Tematchnui vup. Pp.91-94. (Rus)
5. Domnin, I. F., Levon O. O., Varvyanskaya, V. $V$. (2014). Fuzzy logic based control system of converter for powerful sounding pulses generator. Visnuk Nacionalnogo Tehnichnogo Universitetu «Kharkivskiy politehnichnuy institut». Kharkov: NTU«KHPII». No. 47 (1089). Pp. 22-27.

6. Domnin, I. F. (2004). Sistema upravleniya philtrocompensiruyuchim ustroistvom Tehnichna electrodynamika. No. 4. Pp. 25-29. (Rus)

7. Domnin, I. F., Gemerov, G.G., Sokol, Y.I. (2009). Perspectivu primineniya poluprovodnicovuh compensatorov reactivnoi mochnosti $v$ setyah electrosnabgeniya promushlennuh predpriyatiy. Tehnichna electrodynamika. Kiev. IEDNANU. P. 2. Tematchnui vup. Pp. 37-41. (Rus)

Поступила в редакцию 9 августа 2016 г.

\section{УДК 621.314 .26}

Е.А. Левон, канд. техн. наук

Национальный технический университет "Харьковский политехнический институт”, ул. Багалия, 21, г. Харьков, 61002, Украина.

\section{Моделирование переходных процессов в низкочастотном канале полупроводникового регулируемого компенсатора}

В статье рассмотрено моделирование переходных процессов в низкочастотном канале полупроводникового двухканального регулируемого компенсатора неактивних составляющих полной мощности. Предложены методы прогнозного управления двухканальным компенсатором, которые позволяют обеспечить высокие динамические характеристики компенсатора при изменении характера нагрузки. Представлены результаты моделирования, сделаны выводы. Библ. 7, рис. 4.

Ключевые слова: силовая электроника; контроль реактивной мощности; силовой активный фильтр; двухмостовой тиристорный выпрямитель.

\section{УДК 621.314.26}

О. О. Левон, канд. техн. наук

Національний технічний університет “Харківський політехнічний інститут”, вул. Багалія, 21, м. Харків, 61002, Україна.

\section{Моделювання перехідних процесів у низькочастотному каналі напівпровідникового регульованого компенсатора}

У статmі розглянуто моделювання перехідних процесів в низькочастотному каналі напівпровідникового двоканального регульованого компенсатора неактивних складових повної потужності. Запропоновано методи прогнозного керування двоканальним компенсатором, які дозволя- 
ють забезпечити високі динамічні характеристики компенсатора при зміні характеру навантаження. Представлені результати моделювання, зроблені висновки. Бібл. 7, рис. 4.

Ключові слова: силова електроніка; контроль реактивної потужності; силовий активний фільтр; двомостовий тиристорний випрямляч.

\section{Список використаних джерел}

1. Домнин И. Ф., Кайда Е. А. “Динамические характеристики двухмостового низкочастотного канала компенсатора неактивной мощности". -Технічна електродинаміка. - Київ: ІЄДНАНУ. 2009. - Ч. 4, Тематичний вип.- С. 63-67.

2. Домнин И. Ф., Кайда Е. А. "Многоконтурная система управления фрильтрокомпенсирующим устройством ". - Технічна електродинаміка. - Київ: ІЄДНАНУ. - 2010. - Ч. 2, Тематичний вип.C. 44-47.

3. Кайда E. А. "Нечеткое регулирование устройством компенсации неактивных составляющих полной мощности ". - Технічна електродинаміка. - Київ: ІЄДНАНУ. - 2011. - Ч. 1, Тематичний вип. - С. 184-188.

4. Левон Е. А., Домнин И. Ф., Северин В. П. "Оптимизация параметров цифрового нечеткого регулятора". - Технічна електродинаміка. - Харків: НТУ «ХПІ». - 2012. - Ч.2, Тематичний вип. - С. 91-94.

5. Domnin I. F., Levon O. O., Varvyanskaya V. V. "Fuzzy logic based control system of converter for powerful sounding pulses generator". - Вісник Національного технічного університету «Харківський політехнічний інститут». - Харків: НТУ ХПІ». - 2014. - № 47 (1089). - С. 22-27.

6. Домнин И. Ф. "Система управления фильтрокомпенсирующим устройством". - Технічна електродинаміка. - 2004. - № 4. - С. 25-29.

7. Домнин И.Ф., Жемеров Г.Г., Сокол Е.И. “Перспективы применения полупроводниковых компенсаторов реактивной мощности в сетях электроснабжения промышленных предприятий".- Технічна електродинаміка. - Київ: ІЄДНАНУ. - 2009. - Ч. 2, Тематичний вип.C. 37-41. 